\title{
氮水添加改变内蒙古典型草原两种优势植物的 氮吸收偏好
}

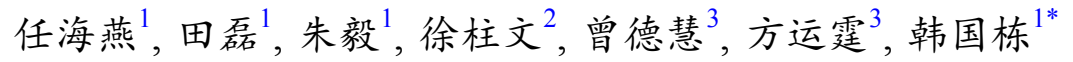

1. 内蒙古农业大学草原与资源环境学院, 草地资源教育部重点实验室, 农业农村部饲草栽培、加工与高效利用重点实验室, 内蒙古自治区草地 管理与利用重点实验室, 呼和浩特 010011 ;

2. 内蒙古大学生态与环境学院, 呼和浩特 010021 ;

3. 中国科学院沈阳应用生态研究所, 沈阳 110016

*联系人, E-mail: hanguodong@imau.edu.cn

2021-11-17 收稿, 2021-12-10 修回, 2021-12-13 接受, 2021-12-14 网络版发表

内蒙古自治区科技重大专项(2020ZD0009)、国家自然科学基金(31760146)、霍英东教育基金(171018)、中央引导地方科技发展资金 (2020ZY0008)、内蒙古自治区应用技术研究与开发资金(2021GG0088)、中国科学院 “西部之光”人才计划、高等学校学科创新引智计划 (D21006)和教育部草地资源可持续利用科技创新团队(IRT_17R59)资助

摘要 植物对不同形态氮的吸收直接影响输入到生态系统中氮的去向和氮动态的变化, 但是资源添加如何影响植 物氮吸收偏好仍不明确. 本研究依托内蒙古典型草原连续开展了 10 年氮、水添加实验平台, 选择克氏针茅 (Stipa krylovii) 和冰草(Agropyron cristatum) 两个优势物种为研究对象, 使用 ${ }^{15} \mathrm{~N}$ 自然丰度法测定植物叶片和土壤各形态氮 含量及其同位素特征，利用同位素混合模型量化不同氮源对植物氮的贡献，探究植物氮吸收偏好及其对资源添加 的响应. 结果表明, (1) 自然状态下硝态氮和铵态氮对植物氮的贡献分别约为 $80 \%$ 和 $20 \%$; (2) 氮添加减小了两种植 物对硝态氮的利用, 水分添加降低了克氏针茅而提高了冰草对硝态氮的利用, 氮、水处理对植物氮吸收偏好的影 响具有显著的交互作用. 结果揭示, 内蒙古典型草原优势植物在自然状态下主要利用较丰富的硝态氮, 对较贫瘩的 铵态氮利用较少; 并且氮吸收特征随着资源添加而改变, 水分对氮吸收的影响受到了氮素供给的调节。未来氮沉 降加剧和硝态氮比例增加并非总是产生负效应, 很可能促进温带草原优势植物的生长, 减缓全球环境变化的生态 后果.

关键词铵态氮, 氮沉降, 降水变化, 稳定同位素技术, 物种组成, 硝态氮

氮是决定陆地生态系统生产力的关键因子 ${ }^{[1,2]}$. 植 物对不同形态氮的吸收偏好直接影响输入到自然生态 系统中氮的去向和氮动态的变化, 对于理解生态系统 氮循环和预测植物对未来环境变化的响应非常重 要 $^{[3,4]}$. 植物主要通过根系从土壤中获取可利用氮, 如硝 态氮、铵态氮和可溶性有机氮, 但是对各形态氮的利 用并非均等. 在某些严重氮限制的生境中植物能够从 土壤中直接吸收氨基酸等小分子有机氮, 如北极和高
山冻原 ${ }^{[5,6]}$ 、北方针叶林 ${ }^{[7]}$ 和高寒草甸 ${ }^{[8,9]}$ 等. 然而在大 多数生态系统中植物仍主要利用无机氮, 并且对硝态 氮和铵态氮的吸收速率存在差异 ${ }^{[10,11]}$. 硝态氮同化之 前要进行还原反应, 铵态氮直接合成谷氨酸, 因此硝态 氮比铵态氮的同化作用能耗多 ${ }^{[12]}$. 然而, 硝态氮比铵态 氮的可移动性强、更容易被植物获取; 硝态氮可以在 植物根部和叶片组织合成有机化合物; 铵态氮仅在吸 收部位附近的根部组织生成氨基酸, 以避免有毒积累.

引用格式: 任海燕, 田否, 朱毅, 等. 氮水添加改变内蒙古典型草原两种优势植物的氮吸收偏好. 科学通报, 2022, 67: 1459-1468 Ren H Y, Tian L, Zhu Y, et al. Nitrogen and water addition alter nitrogen uptake preferences of two dominant plant species in a typical Inner Mongolian steppe (in Chinese). Chin Sci Bull, 2022, 67: 1459-1468, doi: 10.1360/TB-2021-1202 
鉴于此, 土壤硝态氮或铵态氮都有可能成为植物的优 势氮源.

近50年来，植物氮吸收偏好的相关研究在苔原、 森林和草地等各种类型的生态系统开展 ${ }^{[13 ~ 16]}$. 例如, 在 青藏高原草甸草原开展的一项研究表明, 所研究的 11 个常见物种均对铵态氮的利用超过了硝态氮，可能与 土壤中较高的铵态氮含量有关 ${ }^{[16]}$. 对我国东北地区 4 个 主要针叶树种(Pinus koraiensis、Pinus sylvestris、Picea koraiensis、Larix olgensis)的研究表明，成年大树 表现出对硝态氮的高效吸收，占总氮吸收的 $39 \%$ $90 \%{ }^{[17]}$. 目前对植物氮吸收偏好的认识可归纳为两种 观点：(1) 物种对不同形态氮的利用没有专一性，导致 植物群落内部对氮的竞争加强 ${ }^{[18]}$. 例如, 热带森林的 8 个物种对硝态氮、铵态氮和甘氨酸的利用比例没有显 著差异 ${ }^{[19]}$. (2) 物种依赖于土壤中某种特定的氮形态, 即存在专一性，那么氮循环中氮形态的任何变化都会 引起群落组成和物种分布发生变化 ${ }^{[6]}$. 一项北极苔原 的研究表明, 生产力较高的物种主要利用较丰富的铵 态氮和甘氨酸, 而生产力较低的物种则主要利用较贫 痊的硝态氮 ${ }^{[14]}$. 自从浮游生物悖论提出以来 ${ }^{[20]}$, 陆地 植物群落研究和植物竞争理论更关注上述第二种策略, 即物种基于不同的氮吸收偏好划分有限的土壤氮库, 占据相对专一的生态位, 以实现物种共存. 然而在干旱 半干旱区温带草原植物氮吸收的特点仍不明确.

植物氮吸收偏好是否随着资源供给变化而改变没 有一致的结果. 有研究报道, 氮添加会促进或抑制植物 对硝态氮的吸收，因物种而异 ${ }^{[16] ;}$ 然而也有研究表明, 植物对不同形态氮的吸收比例并没有随着氮素供给变 化而改变 ${ }^{[19]}$. 另一方面, 植物氮吸收偏好与水分供给密 切相关. 例如, 对夏威夷热带森林的研究表明, 当年均 降雨量小于 $3350 \mathrm{~mm}$ 时, 植物主要利用硝态氮; 当年均 降雨量大于 $3350 \mathrm{~mm}$ 时, 植物则主要利用铵态氮 ${ }^{[21]}$. 对 非洲稀树草原样带的研究表明, 植物在较干旱环境中 (365 mm) 主要利用硝态氮, 在较湿润环境中 $(400$ $900 \mathrm{~mm}$ ) 主要利用铵态氮 ${ }^{[4]}$. 植物氮吸收对水分变化的 响应很可能与土壤中铵态氮和硝态氮含量的比值有 关 $^{[4]}$. 但是, 氮、水添加如何影响温带草原植物氮吸收 偏好及其相互作用仍未清楚解析.

内蒙古草原是我国北方面积最大、最具有代表性 的草原, 也是欧亚大陆草原的重要组成部分, 被预测对 气候变化非常敏感 ${ }^{[22]}$, 可能由于氮素和水分是本地区 限制植物生长的最重要因子而导致 ${ }^{[23,24]}$. 中国北方未
来夏季降雨增加 ${ }^{[25]}$ 和氮沉降增加 ${ }^{[1,26]}$, 很可能会引起土 壤可利用氮供给能力改变而影响植物对氮素的吸收, 进而影响生态系统过程和功能. 本研究基于内蒙古典 型草原开展了 10 年的氮、水添加实验平台, 利用氮稳 定同位素技术, 量化研究植物氮素来源, 拟解决的关键 问题: (1) 内蒙古典型草原优势植物的氮吸收偏好是什 么? (2) 氮、水添加如何影响植物氮吸收偏好? 二者存 在怎样的相互作用?

\section{1 材料与方法}

\section{1 研究区概况}

本研究区域位于内蒙古自治区锡林郭勒盟东南端 的多伦县 $\left(116^{\circ} 17^{\prime} \mathrm{E}, 42^{\circ} 02^{\prime} \mathrm{N}\right.$, 海拔 $1324 \mathrm{~m}$ a.s.1.), 属温带 大陆性季风气候, 冬季寒冷, 夏季温暖. 年均温度是 $2.1^{\circ} \mathrm{C}$, 1 和 7 月平均温度分别是 -17.5 和 $18.9^{\circ} \mathrm{C}$. 年均降水量 约为 $380 \mathrm{~mm}$, 其中 $80 \%$ 的降水集中在7 9月. 土壤主要 为栗钲土, 平均土壤容重为 $1.21 \mathrm{~g} \mathrm{~cm}^{-3}$, 土壤 $\mathrm{pH} 7.12$. 该地区植物群落的优势物种主要包括克氏针茅 (Stipa krylovii)、冰草(Agropyron cristatum)和冷蒿(Artemisia frigida).

\section{2 实验设计}

实验样地位于多伦恢复生态学实验示范研究站十 三里滩基地，选择地势平坦、植被均匀、有代表性的 地段作为实验区，于2005年设立长期养分和水分添加 实验平台, 采用裂区设计, 水分添加为主因素, 氮、磷 添加为副因素, 共 12 个实验处理. 本研究在实验处理的 第 10 年开展，选择了 4 个处理，包括对照 $(\mathrm{C})$ 、氮添加 $(\mathrm{N})$ 、水分添加 $(\mathrm{W})$ 、氮十水添加 $(\mathrm{WN})$, 每处理设7次重 复, 共 28 个实验小区. 氮添加速率为 $10 \mathrm{~g} \mathrm{~N} \mathrm{~m}^{-2} \mathrm{a}^{-1}$, 每 年在5月中旬和 7 月初分两次进行, 添加的氮素形式为 尿素. 水分添加采用喷灌方式，在生长季内共增雨 $180 \mathrm{~mm}$ (约为该地区年均降水量的一半), 分 12 次进行, 每次 $15 \mathrm{~mm}$, 时间间隔为 $6 \mathrm{~d}$.

\section{3 植物和土壤样品的采集与测定}

植物和土壤样品按照“一对一”的方法进行采集. 在每个实验小区内设置两个 $0.5 \mathrm{~m} \times 0.5 \mathrm{~m}$ 的小样方, 在 每个小样方里收集植物叶片, 取两钻 $0 \sim 10 \mathrm{~cm}$ 土壤混合 作为一个土壤样品. 采集好土壤样品后, 即刻带回实验 室, 将每个土壤样品用 $2 \mathrm{~mm}$ 网篮去除细根(若细根较 
多, 用标签吸附、去除)并充分混匀后分成2份：(1) 1份 为新鲜土样, 其中称取 $20 \mathrm{~g}$ 左右鲜土, 用于测定土壤含 水量; 另外称取 $10 \mathrm{~g}$ 鲜土放人 $100 \mathrm{~mL}$ 的塑料方瓶中, 然 后加入 $50 \mathrm{~mL} 2 \mathrm{~mol} / \mathrm{L}$ 的KCl溶液, 振荡 $1 \mathrm{~h}$ 后, 静置 $30 \mathrm{~min}$ ，将上清液用滤纸过滤到 $50 \mathrm{~mL}$ 的塑料方瓶中, 制成土壤浸提液样品. (2) 剩下的土壤样品自然晾干, 用于测定土壤全氮含量及 ${ }^{15} \mathrm{~N}$ 自然丰度. 植物叶片样品 烘干至恒重, 称重、磨粉.

植物叶片和土壤的全氮浓度及 ${ }^{15} \mathrm{~N}$ 自然丰度值: 使 用同位素质谱仪(Isoprime 100)与元素分析仪(Elementar vario MICRO cube)联用的方法, 对过 80 目篎制成的 叶片和土壤样品进行测定.

土壤无机氮浓度及 ${ }^{15} \mathrm{~N}$ 自然丰度值: 使用连续流动 分析仪(FIAstar 5000 Analyzer, Foss Tecator, Denmark) 对土壤浸提液样品进行测定, 以干土重为基础进行计 算, 得到土壤硝态氮和铵态氮含量, 单位为 $\mathrm{mg} \mathrm{kg}^{-1}$. 之 后土壤浸提液被用来分析硝态氮和铵态氮的氮同位素 特征, 使用镉还原方法 ${ }^{[27]}$ 和次澳酸盐氧化-羟氨还原 ${ }^{[28]}$ 的方法, 分别将硝态氮和铵态氮转化为 $\mathrm{N}_{2} \mathrm{O}$ 气体, 使用 同位素质谱仪-痕量气体模块联用的方法进行测定 ${ }^{[29]}$.

\section{4 数据分析}

${ }^{15} \mathrm{~N}$ 自然丰度法是指利用氮稳定同位素技术测定 土壤可利用氮和植物叶片的 $\delta^{15} \mathrm{~N}$, 通过比较土壤和植物 的 $\delta^{15} \mathrm{~N}$ 值, 确定与植物 $\delta^{15} \mathrm{~N}$ 最接近的土壤氮形态为植物 主要利用的氮形态 ${ }^{[2]}$. 进一步利用IsoSource模型 ${ }^{[30]}$, 量 化土壤不同形态氮对植物氮的贡献.

混合效应模型的裂区设计两因素方差分析用于检 验氮、水处理对土壤不同形态氮含量及同位素特征的 影响. 混合效应模型的裂区设计三因素方差分析用于 检验氮、水和物种对植物氮浓度及同位素特征的影响. 多重比较(Tukey-test)用于检验不同处理之间的显著性 差异. 所有统计分析均使用 $\mathrm{R}$ 软件完成.

\section{2 结果与分析}

\section{1 氮、水添加对土壤不同形态氮含量及同位素 特征的影响}

方差分析结果显示, 氮添加提高了土壤全氮含量 $(P<0.01)$, 水分添加无显著影响, 氮、水的交互作用为 边缘显著 $(P<0.10$, 表 1, 图1(a)). 氮添加提高而水分添加 降低了土壤硝态氮和铵态氮含量 $(P<0.05$, 表 1 , 图1(b), $(\mathrm{c}))$, 氮、水对硝态氮和铵态氮含量的交互作用分别表 现为边缘显著 $(P<0.10)$ 和极显著 $(P<0.01)$.

氮、水添加均使土壤全氮 $\delta^{15} \mathrm{~N}$ 增加 $(P<0.01)$, 但是 二者的交互作用不显著(表1, 图1(d)). 氮添加降低而水 分添加提高了土壤硝态氮 $\delta^{15} \mathrm{~N}$, 并且二者具有显著的交 互作用 $(P<0.01$, 表 1 , 图 $1(\mathrm{e}))$. 氮添加减小了土壤铵态氮 $\delta^{15} \mathrm{~N}(P<0.10)$, 水分添加无显著影响, 氮水处理具有显 著的交互作用 $(P<0.05$, 表1, 图1(f)).

\section{2 氮、水添加对植物叶片氮浓度及同位素特征的 影响}

在对照小区中，冰草的叶片氮浓度 $(1.50 \%)$ 显著高 于克氏针茅(1.15\%)(图2(a)). 氮添加提高了两种植物的 叶片氮浓度, 水分添加无显著影响, 氮、水处理对叶片 氮浓度的交互作用显著 $(P<0.001$, 表2, 图2(a)).

在自然状态下，冰草的叶片 $\delta^{15} \mathrm{~N}$ 为 $-1.84 \%$, 克氏针 茅的叶片 $\delta^{15} \mathrm{~N}$ 为 $-1.50 \%$ (图2(b)), 两物种间无显著差异. 与对照相比, 氮、水添加均使两种植物的叶片 $\delta^{15} \mathrm{~N}$ 显著 提高, 并且氮、水处理对叶片 $\delta^{15} \mathrm{~N}$ 的交互影响显著 $(P<0.01$, 表2, 图2(b)).

\section{3 氮、水添加对植物氮素来源的影响}

为量化植物氮素来源, 将植物叶片与土壤各形态 氮的 $\delta^{15} \mathrm{~N}$ 值做差值比较, 结果表明, 在对照小区中, 克 氏针茅叶片与土壤硝态氮、铵态氮的 $\delta^{15} \mathrm{~N}$ 差值分别 为 $-2.13 \% \pm 0.08 \% 、 7.10 \% \pm 0.10 \%$, 氮、水添加均增大 了叶片与硝态氮 $\delta^{15} \mathrm{~N}$ 的差异、减小了叶片与铵态氮 $\delta^{15} \mathrm{~N}$ 的差异(图3(a)). 同位素混合模型进一步表明, 在自 然状态下土壤硝态氮、铵态氮对克氏针茅叶片氮的贡 献分别为 $77 \% 、 23 \%$; 氮、水添加均减小了硝态氮而增 加了铵态氮对克氏针茅的贡献(图3(c)).

在对照小区中，冰草叶片与土壤硝态氮、铵态氮 的 $\delta^{15} \mathrm{~N}$ 差值分别为 $-1.80 \% \pm 0.20 \% 、 7.43 \% 0 \pm 0.23 \%$ ，氮 添加增大了冰草与硝态氮 $\delta^{15} \mathrm{~N}$ 的差异、减小了冰草与 铵态氮 $\delta^{15} \mathrm{~N}$ 的差异，水分添加则减小了冰草与硝态氮 $\delta^{15} \mathrm{~N}$ 的差异(图3(b)). 同位素混合模型显示, 对照条件 下硝态氮、铵态氮对冰草叶片氮的贡献分别为 $81 \%$ 、 $19 \%$; 氮添加减小了硝态氮的贡献, 增加了辖态氮的贡 献; 水分添加则提高了硝态氮的贡献, 降低了铵态氮对 冰草的贡献(图3(d)).

方差分析表明，氮、水对植物氮源贡献的影响具 有显著的交互作用 $(P<0.01 ，$ 表 2$)$. 不论是否增水, 氮添 
表 1 氮(N)、水 $(W)$ 添加对土壤各形态氮含量及其同位素特征影响的混合效应模型方差分析 $(F \text { 值 })^{a}$

Table 1 ANOVA results from mixed model on the effects of nitrogen $(\mathrm{N})$ and water addition $(\mathrm{W})$ on soil nitrogen concentration and isotope $(F$ value)

\begin{tabular}{ccccccccc}
\hline 处理 & $\mathrm{d} f_{\text {num }}$ & $\mathrm{d} f_{\mathrm{den}}$ & 土壤全氮 & 土壤 $\mathrm{NO}_{3}{ }^{-}$ & 土壤 $\mathrm{NH}_{4}{ }^{+}$ & 土壤全氮 $\delta^{15} \mathrm{~N}$ & $\delta^{15}{\mathrm{~N}-\mathrm{NO}_{3}}^{-}$ & $\delta^{15}{\mathrm{~N}-\mathrm{NH}_{4}}^{+}$ \\
$\mathrm{N}$ & 1 & 9 & $10.85^{* *}$ & $162.28^{* * *}$ & $324.18^{* * *}$ & $27.24^{* * *}$ & $187.69^{* * *}$ & $3.31^{\wedge}$ \\
$\mathrm{W}$ & 1 & 9 & 0.93 & $4.85^{*}$ & $26.31^{* *}$ & $19.17^{* *}$ & $82.07^{* * *}$ & 0.68 \\
$\mathrm{~N} \times \mathrm{W}$ & 1 & 9 & $3.40^{\wedge}$ & $3.99^{\wedge}$ & $27.04^{* *}$ & 0.17 & $31.82^{* *}$ & $4.85^{*}$ \\
\hline
\end{tabular}

a) $\mathrm{d} f_{\text {num }}$ 表示分子自由度, $\mathrm{d} f_{\mathrm{den}}$ 表示分母自由度; 显著性水平: ^ $P<0.10 ; * P<0.05 ; * * P<0.01 ; * * * P<0.001$
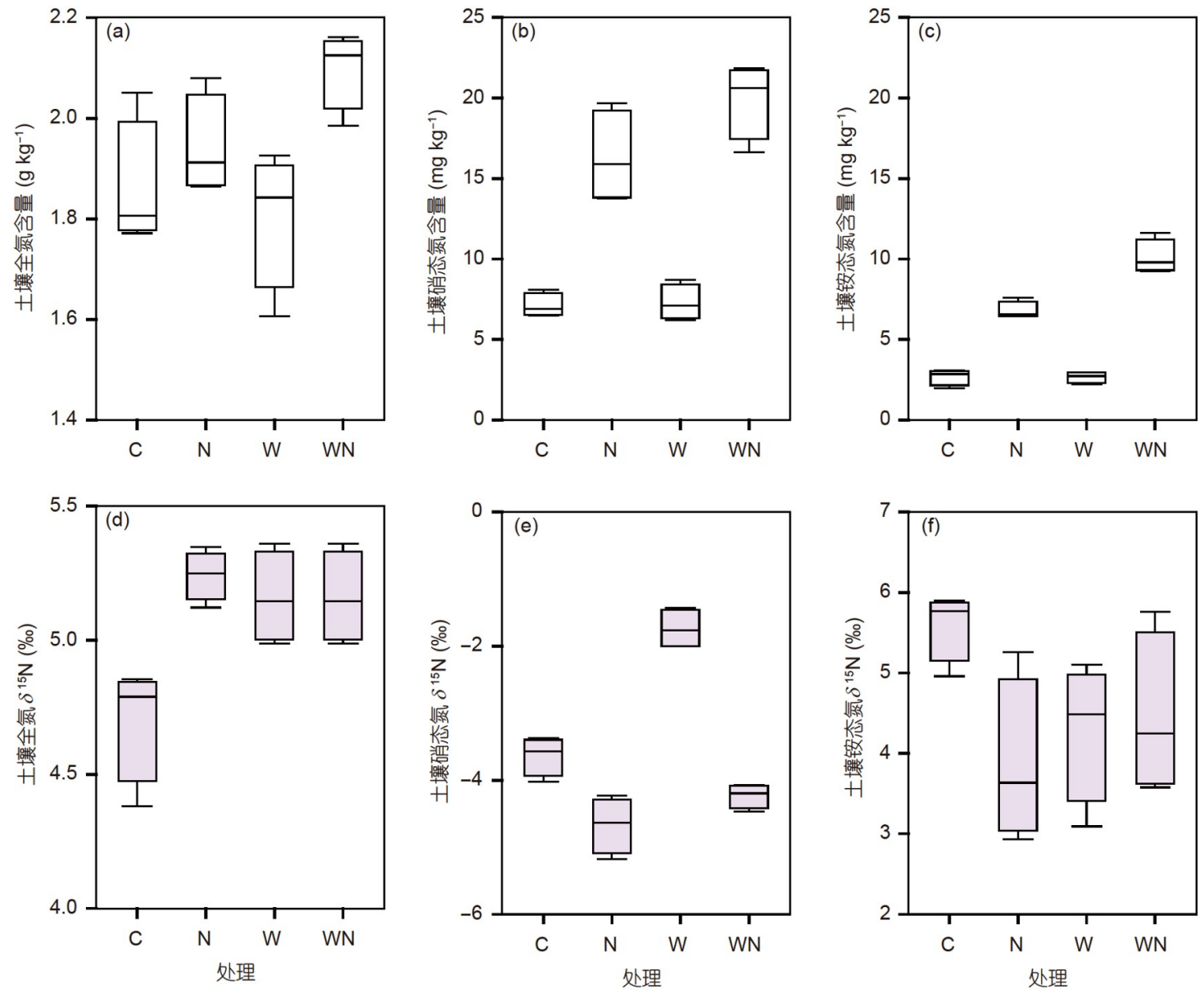

图 1 (网络版彩色)土壤各形态氮含量(a) (c)及其同位素特征(d) (f)对氮、水添加的响应

Figure 1 (Color online) The responses of soil nitrogen content (a)-(c) and isotope (d)-(f) to nitrogen and water addition

加均使两种植物对硝态氮的利用降低(图4(a))，对铵态 氮的利用提高(图4(b)). 在加氮条件下，水分添加提高 了两种植物对硝态氮的利用; 在不加氮条件下, 水分添 加提高了冰草而降低了克氏针茅对硝态氮的利用(图4 (c)). 水分添加在加氮条件下减小了两种植物对铵态氮 的利用，在不加氮条件下提高了克氏针茅而降低了冰 草对铵态氮的利用(图4(d)).

\section{3 讨论}

\section{1 植物的氮吸收偏好特征及其量化方法}

氮是限制草地生产力的主要养分元素，不同草地 植物可能表现不同的氮吸收偏好(喜铵或者喜硝), 与物 种优势度密切相关 ${ }^{[14]}$. 然而植物氮吸收是否存在偏好 仍有争议. 本研究显示, 在自然状态下, 所研究样地中 

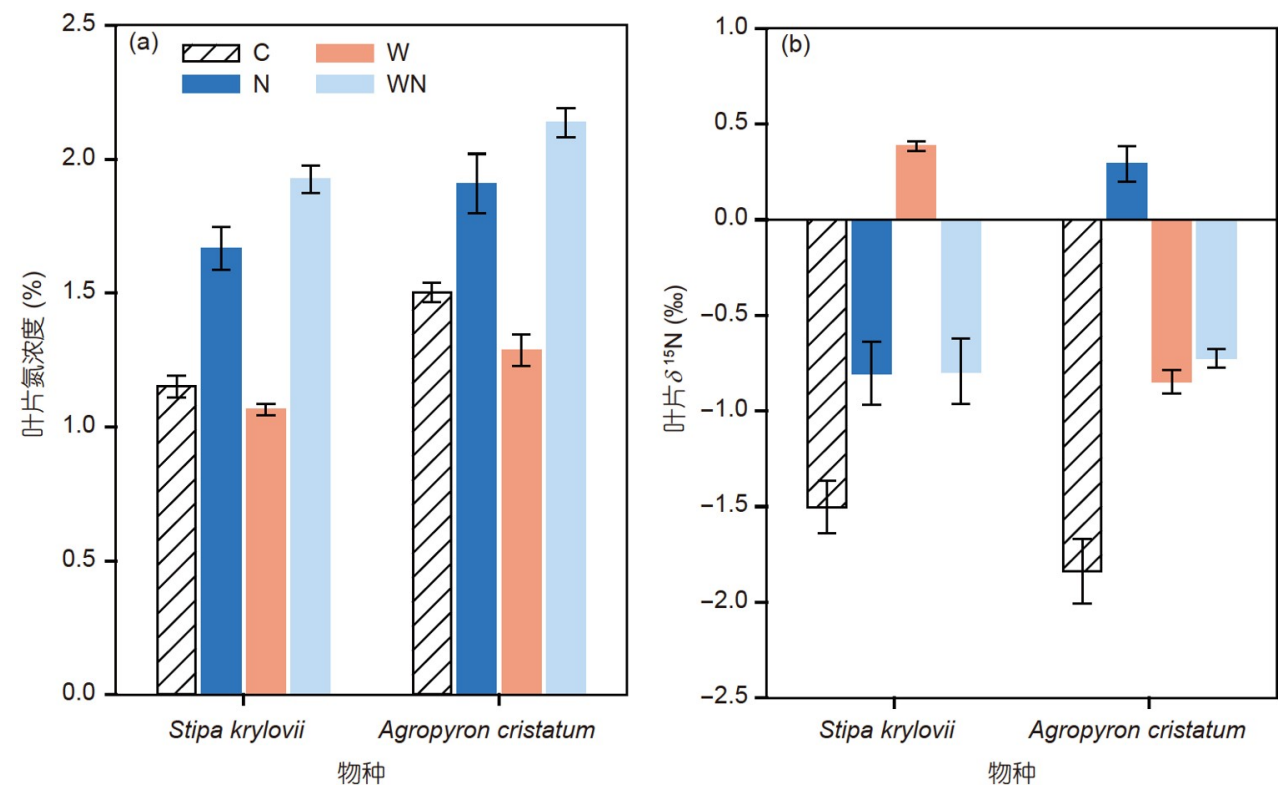

图 2 (网络版彩色)植物氮浓度(a)及其同位素特征(b)对氮、水添加的响应

Figure 2 (Color online) The responses of leaf nitrogen concentration (a) and isotope (b) to nitrogen and water addition

表 2 氮 $(\mathrm{N})$ 、水 $(\mathrm{W})$ 和物种 $(\mathrm{S})$ 对叶片氮含量及其同位素特征影响的混合效应模型方差分析 $(F \text { 值 })^{\mathrm{a})}$

Table 2 ANOVA results from mixed model on the effects of nitrogen $(\mathrm{N})$, water $(\mathrm{W})$ and species $(\mathrm{S})$ on leaf $\mathrm{N}$ concentration and isotope $(F$ value)

\begin{tabular}{ccccccccc}
\hline 处理 & $\mathrm{d} f_{\text {num }}$ & $\mathrm{d} f_{\text {den }}$ & 叶氮浓度 & 叶片 $\delta^{15} \mathrm{~N}$ & $\delta^{15} \mathrm{~N}_{\text {leaf-NO3 }}$ & $\delta^{15} \mathrm{~N}_{\text {leaf-NH4 }}$ & $\delta^{15} \mathrm{~N}_{\text {leaf-total N }}$ & 氮源贡献 \\
\hline $\mathrm{N}$ & 1 & 9 & $490.08^{* * *}$ & $19.92^{* *}$ & $279.07^{* * *}$ & $10.89^{* *}$ & 0.22 & $181.57^{* * *}$ \\
$\mathrm{~W}$ & 1 & 9 & 2.42 & $21.86^{* *}$ & $27.80^{* * *}$ & $4.89^{*}$ & 0.21 & $5.50^{*}$ \\
$\mathrm{~S}$ & 1 & 12 & $39.93^{* * *}$ & 2.29 & 2.24 & 2.26 & 2.43 & $6.00^{*}$ \\
$\mathrm{~N} \times \mathrm{W}$ & 1 & 9 & $44.22^{* * *}$ & $95.12^{* * *}$ & $3.42^{\wedge}$ & $26.63^{* * *}$ & $66.44^{* * *}$ & $20.91^{* *}$ \\
$\mathrm{~N} \times \mathrm{S}$ & 1 & 12 & 0.55 & $109.29^{* * *}$ & $108.32^{* * *}$ & $109.71^{* * *}$ & $111.34^{* * *}$ & $78.05^{* * *}$ \\
$\mathrm{~W} \times \mathrm{S}$ & 1 & 12 & 0.91 & $54.34^{* * *}$ & $53.26^{* * *}$ & $54.02^{* * *}$ & $54.74^{* * *}$ & $45.05^{* * *}$ \\
$\mathrm{~N} \times \mathrm{W} \times \mathrm{S}$ & 1 & 12 & 0.38 & 0.25 & 0.26 & 0.26 & 0.26 & 1.66 \\
\hline
\end{tabular}

a) $\mathrm{d} f_{\text {num }}$ 表示分子自由度, $\mathrm{d} f_{\mathrm{den}}$ 表示分母自由度; 显著性水平: ^ $P<0.10 ; * P<0.05 ; * * P<0.01 ; * * * P<0.001$

硝态氮 $\left(7.10 \pm 0.37 \mathrm{mg} \mathrm{kg}^{-1}\right)$ 为土壤中较丰富的氮形态, 铵态氮 $\left(2.68 \pm 0.25 \mathrm{mg} \mathrm{kg}^{-1}\right)$ 为较贫㾑的氮形态. 内蒙古 典型草原优势植物克氏针茅和冰草对硝态氮的利用率 分别为 $77 \% 、 81 \%$, 对铵态氮的利用率分别为 $23 \%$ 、 $19 \%$ ，表明优势植物主要利用较丰富的氮形态——硝 态氮，而对铵态氮的利用较少. 对我国东北地区 4 个主 要针叶树种(红松、云杉、樟子松和落叶松)的研究表 明, 所研究植物均表现出对硝态氮(土壤中的优势氮源) 的高效吸收，占总氮吸收的 $39 \% \sim 90 \%{ }^{[17,31]}$. McKane等 人 $^{[14]}$ 对北极苔原的研究表明, 较高生产力的植物主要 利用土壤中较丰富的氮形态(铵态氮和甘氨酸), 而较低
生产力的植物则对较贫㾑的硝态氮利用较高. 上述研 究与本研究结果一致, 表明生态系统中的优势植物对 土壤不同形态氮的利用并非均等，而是对较丰富氮形 态的利用比例较高, 植物氮吸收存在偏好. 另一方面, 在巴拿马热带山地森林开展的幼苗移植实验表明，所 研究的 11 个物种中仅有 5 个物种对某种氮形态表现出 很弱的偏好, 其他物种均无氮吸收偏好 ${ }^{[32]}$. 该研究与本 研究的结果不一致, 可能与不同的生态系统中土壤硝 态氮和铵态氮含量的比例不同有关. 本研究结果表明, 内蒙古典型草原的 2 个重要物种克氏针茅和冰草表现 出对硝态氮的高效吸收, 约占总氮吸收的 $80 \%$, 而对土 

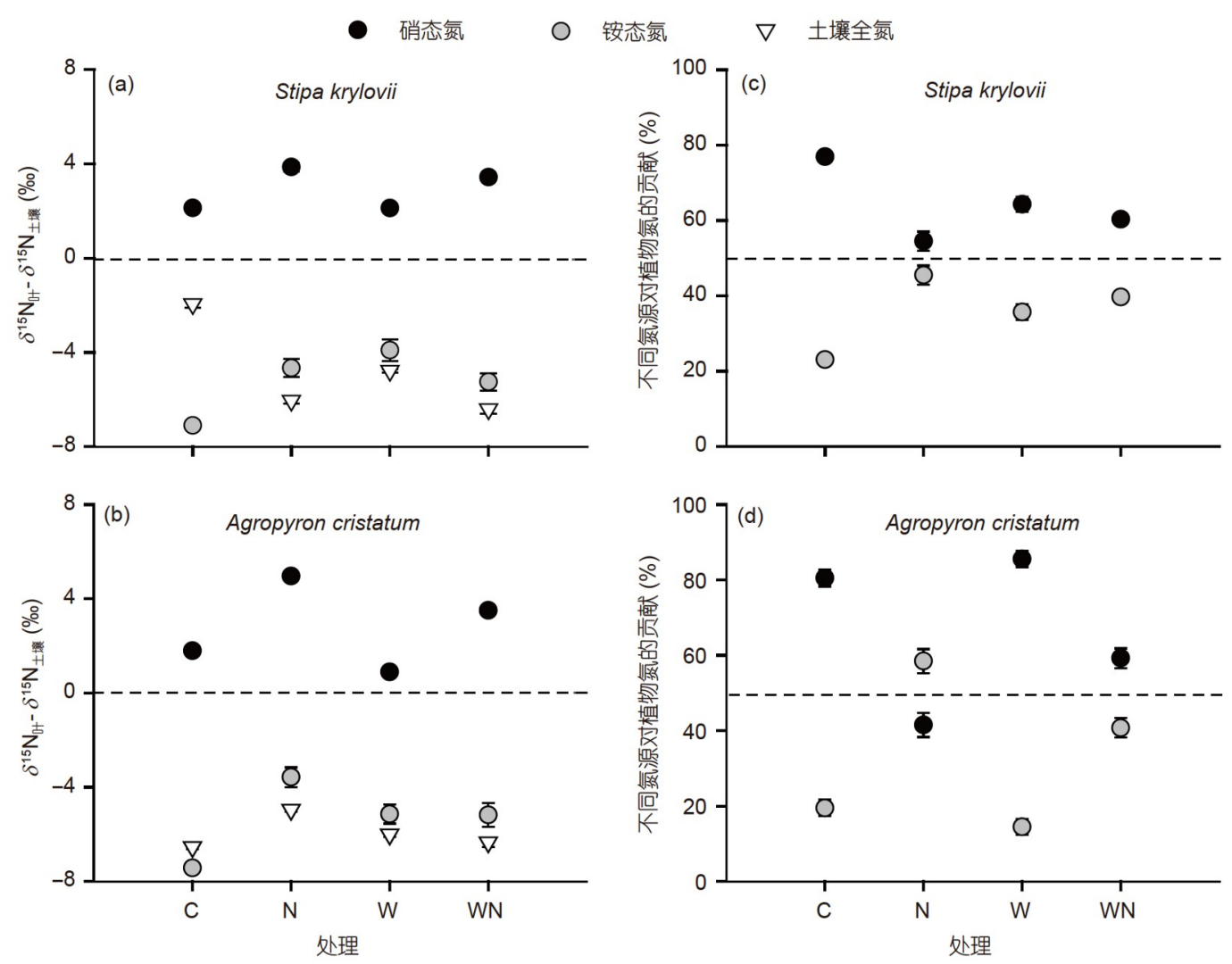

图 3 内蒙古典型草原优势植物叶片 $\delta^{15} \mathrm{~N}$ 与土壤各形态氮 $\delta^{15} \mathrm{~N}$ 的差值 $(\mathrm{a}, \mathrm{b})$ 及不同氮源对植物氮的贡献 $(\mathrm{c}, \mathrm{d})$

Figure 3 The difference between leaf $\delta^{15} \mathrm{~N}$ and soil nitrogen sources $(\mathrm{a}, \mathrm{b})$ and mixing analysis of the proportion of plant nitrogen derived from nitrogen sources $(\mathrm{c}, \mathrm{d})$

壤中较贫痊的铵态氮利用较少. 植物氮吸收特征很可 能与物种优势度密切相关, 将在物种多度分布形成中 发挥重要作用.

植物氮吸收偏好的量化方法与技术, 曾一度成为 难题和争议的热点. 不同的研究采用不同的方法和指 标, 如水培法、 ${ }^{15} \mathrm{~N}$ 标记法、 ${ }^{15}$ 自然丰度法等, 目前没有 统一的量化方法 ${ }^{[33]}$. 本研究采用野外原位 ${ }^{15} \mathrm{~N}$ 自然丰度 法，即通过测定植物组织和土壤各形态氮的同位素值, 使用IsoSource模型 ${ }^{\left[{ }^{[30]}\right.}$ 计算得到不同氮源对植物氮的贡 献比例 ${ }^{[21,34,35]}$. 因为植物和土壤 ${ }^{15} \mathrm{~N}$ 自然丰度值是一段 时间内的积累，所以该方法反映了长期的植物氮吸收 特征. 不足之处是, 植物对不同形态氮吸收的分馏作用 不同，可能带来一定的不确定性. 尽管 ${ }^{15} \mathrm{~N}$ 标记技术不 受稳定同位素分馏效应的影响，但这是一个相对瞬时 的测定过程, 需要考虑标记样品的均匀性、标记期长 短和条件、示踪期长短和各库转化及所追踪的各个库 是否全面等问题. 在未来的研究中, 对 ${ }^{15} \mathrm{~N}$ 自然丰度法 和 ${ }^{15} \mathrm{~N}$ 标记法两种方法进行检验与验证很有意义.

\section{2 植物氮吸收偏好对资源添加的响应}

本研究表明，植物氮吸收偏好随着氮水资源添加 而改变. 氮添加降低了克氏针茅和冰草对硝态氮的利 用, 提高了其对铵态氮的利用. Song等人 ${ }^{[16]}$ 基于青藏高 原草甸草原施肥实验, 研究表明, 氮添加对植物氮吸收 的影响因物种而异, 表现为促进或抑制作用. 上述结果 均表明, 植物氮吸收偏好会随着环境变化而改变. 相反 地, Andersen和Turner ${ }^{[19]}$ 通过氮梯度(高水平、适中、 低水平氮素供给)实验表明，植物氮吸收偏好没有随着 土壤可利用氮的变化而改变, 即植物氮吸收不具有可 塑性. 此外, 克氏针茅氮吸收对水分处理的响应与对氮 添加的响应一致，即水分添加使克氏针茅对硝态氮的 利用减少、对铵态氮的利用增加. 然而与克氏针茅的 响应不同, 在水分添加条件下, 冰草对硝态氮的吸收提 高、对铵态氮的吸收降低. 在增水小区中, 土壤硝态氮 含量 $\left(7.27 \pm 0.55 \mathrm{mg} \mathrm{kg}^{-1}\right)$ 显著高于铵态氮含量 $\left(2.66 \pm 0.17 \mathrm{mg} \mathrm{kg}^{-1}\right)$, 冰草对优势氮源的利用比例增加, 

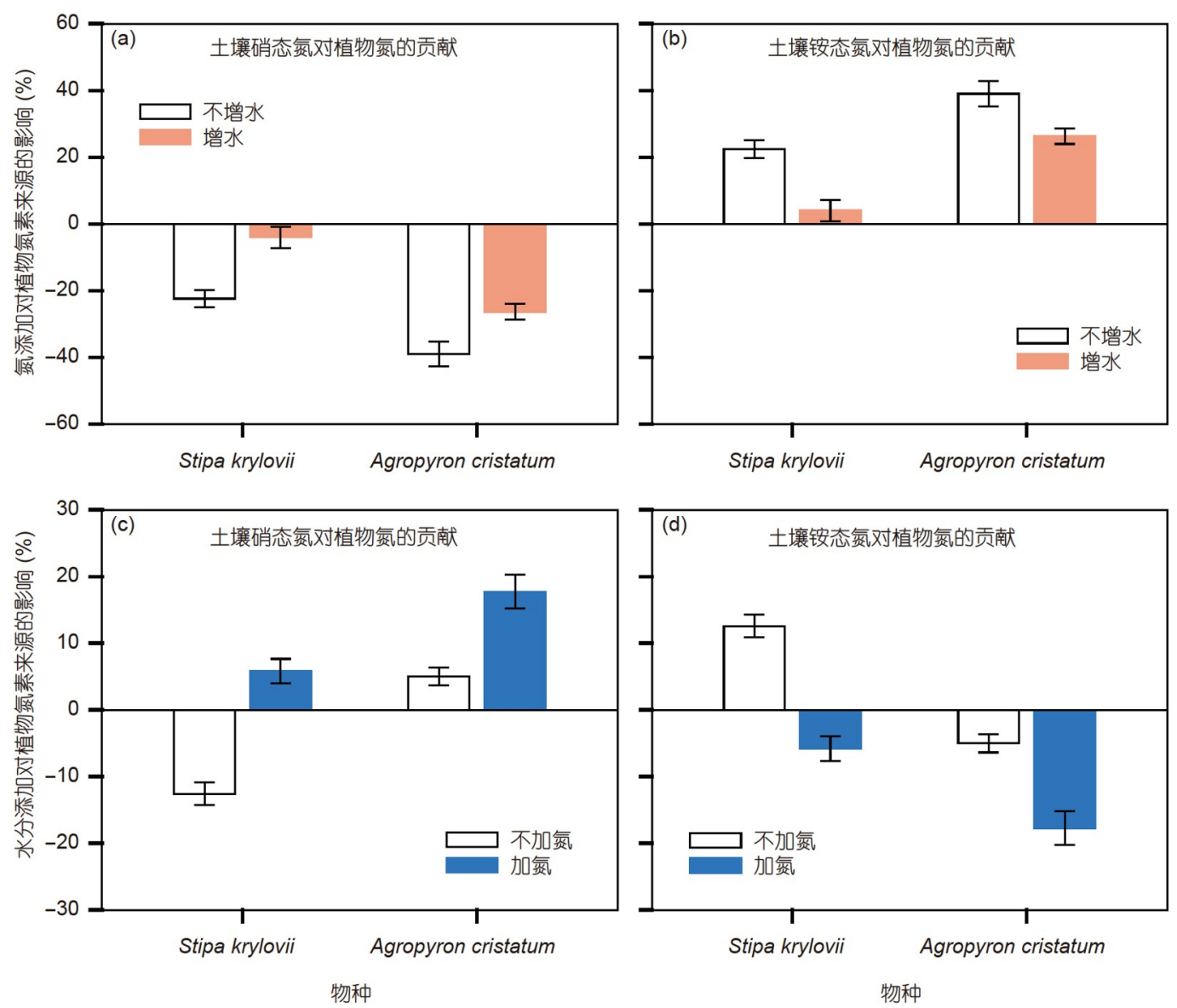

图 4 (网络版彩色)在不增水和增水条件下氮添加对植物氮素来源的相对影响(a, b), 及在不加氮和加氮条件下水分添加对植物氮素来源的相 对影响(c, d)

Figure 4 (Color online) The relative effects of nitrogen addition on proportion of plant nitrogen at ambient and increased water levels (a, b), and the relative effects of water addition on proportion of plant nitrogen at ambient and increased nitrogen levels (c, d)

这很可能是长期增水导致冰草生物量增加、相对多度 增加的重要原因 ${ }^{[24]}$. 植物氮吸收偏好随着水分供给变 化而改变, 这样的可塑性在其他研究中也被报道. Houlton等人 ${ }^{[21]}$ 对 6 个夏威夷热带森林的研究表明，植物氮 吸收偏好与降雨量有关, $3350 \mathrm{~mm}$ 为阈值, 当年均降雨 量大于该阈值时, 植物主要利用铵态氮; 当年均降雨量 小于该阈值时, 植物主要利用硝态氮. Wang和Macko ${ }^{[4]}$ 通过大田和盆栽实验, 对4片非洲稀树草原的研究表明, 在相对湿润的草地(年均降雨量400 900 mm)，优势植 物主要利用铵态氮; 在相对干旱的草地(年均降雨量 $365 \mathrm{~mm}$ ), 优势植物主要利用硝态氮. 综上所述, 植物 氮吸收偏好随着氮水供给变化而表现出的可塑性，很 可能与土壤中铵态氮和硝态氮含量的比值有关.

气候变化与其他全球变化因子之间的交互作用被 预测在驱动生态系统氮循环响应中非常重要 ${ }^{[23]}$, 植物
氮吸收作为氮循环的关键过程，在本研究中受到了氮 水处理显著的交互影响, 影响程度因物种而异. 不论加 氮与否，水分添加均使冰草对硝态氮的利用增加、对 铵态氮的利用减小, 并且在加氮条件下变异程度更大. 具体来讲，在加氮条件下水分处理提高了克氏针茅对 硝态氮的利用，降低了其对铵态氮的利用; 在不加氮条 件下水分处理则降低了克氏针茅对硝态氮的利用，提 高了其对铵态氮的利用. 这些结果表明, 水分对植物氮 吸收的影响依赖于氮素供给. 长期增水很可能导致草 地资源限制类型从水氮共限制向独立氮限制转变 ${ }^{[24]}$.

\section{4 结论}

本研究揭示，内蒙古典型草原优势植物克氏针茅 和冰草对土壤氮的吸收存在偏好，对硝态氮(土壤中较 丰富的氮形态)的利用达到 $80 \%$ 左右，对铵态氮(土壤中 
较贫㾑的氮形态)的利用约为 $20 \%$. 氮水野外控制实验 进一步表明, 植物氮吸收偏好随着资源添加而改变, 体 现为，氮添加降低了两种优势植物对硝态氮的利用、 提高了其对铵态氮的利用; 水分的影响则因物种而异, 水分添加降低了克氏针茅而提高了冰草对硝态氮的 利用。

水、氮处理对植物氮吸收具有显著的交互作用, 水分添加减弱了氮添加引起的植物氮吸收变异程度, 同时氮素供给调控了植物氮吸收对水分变化的响应. 水分添加在加氮条件下提高了克氏针茅对硝态氮的利 用, 在不加氮条件下则相反. 值得注意的是, 本研究以
两个优势物种为研究对象，克氏针茅和冰草均为 $\mathrm{C}_{3}$ 禾 本科植物, 对于其他优势度和光合型的植物, 如 $\mathrm{C}_{4}$ 植物 或杂类草, 还有待研究和检验其对资源添加的响应. 随 着氮沉降全球化增加趋势, 氮沉降中铵态氮和硝态氮 的比例从 20 世纪 80 年代的 $5: 1$ 降低到当前的 $2: 1$, 即氮 沉降中硝态氮浓度增加得更快 ${ }^{[36,37]}$, 可能对生态系统 过程和功能产生负效应. 然而本研究表明了草原优势 植物对硝态氮的高效利用能力，暗示氮沉降加剧和硝 态氮比例增加并非对优势物种生长不利, 将有助于预 测氮沉降和降水变化对草地生态系统功能和物种组成 的影响及其相互作用.

\section{参考文献}

1 Du E, Terrer C, Pellegrini A F A, et al. Global patterns of terrestrial nitrogen and phosphorus limitation. Nat Geosci, 2020 , 13: 221-226

2 LeBauer D S, Treseder K K. Nitrogen limitation of net primary productivity in terrestrial ecosystems is globally distributed. Ecology, 2008, 89: 371-379

3 Reich P B, Hobbie S E, Lee T, et al. Nitrogen limitation constrains sustainability of ecosystem response to CO 2 . Nature, 2006, 440: $922-925$

4 Wang L, Macko S A. Constrained preferences in nitrogen uptake across plant species and environments. Plant Cell Environ, 2011, 34: 525-534

5 Chapin Ш F S, Moilanen L, Kielland K. Preferential use of organic nitrogen for growth by a non-mycorrhizal arctic sedge. Nature, 1993, 361: 150153

6 Nordin A, Schmidt I K, Shaver G R. Nitrogen uptake by arctic soil microbes and plants in relation to soil nitrogen supply. Ecology, 2004, 85: 955962

7 Näsholm T, Ekblad A, Nordin A, et al. Boreal forest plants take up organic nitrogen. Nature, 1998, 392: 914-916

8 Jiang L, Wang S, Pang Z, et al. Grazing modifies inorganic and organic nitrogen uptake by coexisting plant species in alpine grassland. Biol Fertil Soils, 2015, 52: 211-221

$9 \mathrm{Xu}$ X, Ouyang H, Kuzyakov Y, et al. Significance of organic nitrogen acquisition for dominant plant species in an alpine meadow on the Tibet Plateau, China. Plant Soil, 2006, 285: 221-231

10 Kahmen A, Wanek W, Buchmann N. Foliar $\delta^{15} \mathrm{~N}$ values characterize soil N cycling and reflect nitrate or ammonium preference of plants along a temperate grassland gradient. Oecologia, 2008, 156: 861-870

11 Kronzucker H J, Siddiqi M Y, Glass A D M. Conifer root discrimination against soil nitrate and the ecology of forest succession. Nature, 1997, 385: $59-61$

12 Engels C, Marschner H. Plant uptake and utilization of nitrogen. In: Bacon P, ed. Nitrogen Fertilization in the Environment. Sydney: Woodlots \& Wetlands Pty Ltd, 1995. 41-81

13 Liu X Y, Koba K, Koyama L A, et al. Nitrate is an important nitrogen source for arctic tundra plants. Proc Natl Acad Sci USA, 2018, 115: 33983403

14 McKane R B, Johnson L C, Shaver G R, et al. Resource-based niches provide a basis for plant species diversity and dominance in Arctic tundra. Nature, 2002, 415: 68-71

15 Pang Z, Jiang L, Wang S, et al. Differential response to warming of the uptake of nitrogen by plant species in non-degraded and degraded alpine grasslands. J Soils Sediments, 2019, 19: 2212-2221

16 Song M H, Zheng L L, Suding K N, et al. Plasticity in nitrogen form uptake and preference in response to long-term nitrogen fertilization. Plant Soil, 2015, 394: 215-224

17 Zhou X, Wang A, Hobbie E A, et al. Mature conifers assimilate nitrate as efficiently as ammonium from soils in four forest plantations. New Phytol, 2021, 229: 3184-3194

18 Harrison K A, Bol R, Bardgett R D. Preferences for different nitrogen forms by coexisting plant species and soil microbes. Ecology, 2007, 88: 989999

19 Andersen K M, Turner B L. Preferences or plasticity in nitrogen acquisition by understorey palms in a tropical montane forest. J Ecol, 2013, 101: $819-825$ 
20 Hutchinson G E. The paradox of the plankton. Am Nat, 1961, 95: 137-145

21 Houlton B Z, Sigman D M, Schuur E A G, et al. A climate-driven switch in plant nitrogen acquisition within tropical forest communities. Proc Natl Acad Sci USA, 2007, 104: 8902-8906

22 Christensen L, Coughenour M B, Ellis J E, et al. Vulnerability of the Asian typical steppe to grazing and climate change. Clim Change, 2004, 63: 351-368

23 Ren H, Kang J, Yuan Z, et al. Responses of nutrient resorption to warming and nitrogen fertilization in contrasting wet and dry years in a desert grassland. Plant Soil, 2018, 432: 65-73

24 Ren $\mathrm{H}, \mathrm{Xu} \mathrm{Z}$, Isbell F, et al. Exacerbated nitrogen limitation ends transient stimulation of grassland productivity by increased precipitation. Ecol Monogr, 2017, 87: 457-469

25 Cholaw B, Cubasch U, Yonghui L, et al. The change of North China climate in transient simulations using the IPCC SRES A2 and B2 scenarios with a coupled atmosphere-ocean general circulation model. Adv Atmos Sci, 2003, 20: 755-766

26 Galloway J N, Townsend A R, Erisman J W, et al. Transformation of the nitrogen cycle: Recent trends, questions, and potential solutions. Science, 2008, 320: 889-892

27 Tu Y, Fang Y, Liu D, et al. Modifications to the azide method for nitrate isotope analysis. Rapid Commun Mass Spectrom, 2016, 30: 1213-1222

28 Liu D, Fang Y, Tu Y, et al. Chemical method for nitrogen isotopic analysis of ammonium at natural abundance. Anal Chem, 2014, 86: 3787-3792

29 Liu D W, Tu Y, Fang Y T. Isotope analysis of ammonium and nitrate: A review on measured methods and their application (in Chinese). Chin J Appl Ecol, 2017, 28: 2353-2360 [刘冬伟, 图影, 方运霆. 铵盐和硝酸盐稳定同位素丰度测定方法及其应用案例. 应用生态学报, 2017, 28: 2353-2360]

30 Phillips D L, Gregg J W. Source partitioning using stable isotopes: Coping with too many sources. Oecologia, 2003, 136: 261-269

31 Zhu F, Dai L, Hobbie E A, et al. Quantifying nitrogen uptake and translocation for mature trees: An in situ whole-tree paired ${ }^{15} \mathrm{~N}$ labeling method. Tree Physiol, 2021, 41: 2109-2125

32 Andersen K M, Mayor J R, Turner B L. Plasticity in nitrogen uptake among plant species with contrasting nutrient acquisition strategies in a tropical forest. Ecology, 2017, 98: 1388-1398

33 Fang Y T, Liu D W, Zhu F F, et al. Applications of nitrogen stable isotope techniques in the study of nitrogen cycling in terrestrial ecosystems (in Chinese). Chin J Plant Ecol, 2020, 44: 373-383 [方运霆, 刘冬伟, 朱飞飞, 等.氮稳定同位素技术在陆地生态系统氮循环研究中的应用. 植物生 态学报, 2020, 44: 373-383]

34 Takebayashi Y, Koba K, Sasaki Y, et al. The natural abundance of ${ }^{15} \mathrm{~N}$ in plant and soil-available $\mathrm{N}$ indicates a shift of main plant $\mathrm{N}$ resources to $\mathrm{NO}_{3}{ }^{-}$from $\mathrm{NH}_{4}{ }^{+}$along the $\mathrm{N}$ leaching gradient. Rapid Commun Mass Spectrom, 2010, 24: 1001-1008

35 Yang L, He T, Yu Y, et al. Community-wide consistence in plant N acquisition during post-agricultural succession in a karst area, Southwest China. New For, 2018, 49: 197-214

36 Liu X, Zhang Y, Han W, et al. Enhanced nitrogen deposition over China. Nature, 2013, 494: 459-462

37 Zhao Y, Zhang L, Chen Y, et al. Atmospheric nitrogen deposition to China: A model analysis on nitrogen budget and critical load exceedance. Atmos Environ, 2017, 153: 32-40 


\title{
Nitrogen and water addition alter nitrogen uptake preferences of two dominant plant species in a typical Inner Mongolian steppe
}

\author{
Haiyan Ren ${ }^{1}$, Lei $\operatorname{Tian}^{1}$, Yi Zhu ${ }^{1}$, Zhuwen $\mathrm{Xu}^{2}$, Dehui Zeng ${ }^{3}$, Yunting Fang ${ }^{3}$ \& Guodong Han $^{1 *}$ \\ ${ }^{1}$ Key Laboratory of Grassland Management and Utilization of Inner Mongolia, Key Laboratory of Forage Cultivation, Processing and High Efficient \\ Utilization of the Ministry of Agriculture and Rural Affairs, Key Laboratory of Grassland Resources of the Ministry of Education, College of \\ Grassland, Resources and Environment, Inner Mongolia Agricultural University, Hohhot 010011, China; \\ ${ }^{2}$ School of Ecology and Environment, Inner Mongolia University, Hohhot 010021, China; \\ ${ }^{3}$ Institute of Applied Ecology, Chinese Academy of Sciences, Shenyang 110016, China \\ * Corresponding author, E-mail: hanguodong@imau.edu.cn
}

The preferences for different nitrogen $(\mathrm{N})$ forms by plants play an important role in determining the fate and dynamics of $\mathrm{N}$ in ecosystems. Nevertheless, it remains unclear whether and how resource addition influences $\mathrm{N}$ uptake preferences of plants. Here we investigated the effects of long-term (10 a) $\mathrm{N}$ and water addition on plant $\mathrm{N}$ uptake in a temperate semi-arid grassland. We used the ${ }^{15} \mathrm{~N}$ natural abundance technique to measure $\mathrm{N}$ content and isotope in soils and leaves of two dominant plant species, Stipa krylovii and Agropyron cristatum, and quantified the proportion of plant $\mathrm{N}$ derived from different $\mathrm{N}$ sources with an isotopic mixing model. We found that $\mathrm{N}$ addition, but not water addition, significantly increased soil nitrate and ammonium content, and also enhanced plant leaf $\mathrm{N}$ concentration. Soil nitrate accounted for $80 \%$ and ammonium for $20 \%$ contributing to plant $\mathrm{N}$ in non-treated controls. Compared to the controls, $\mathrm{N}$ addition reduced nitrate uptake of the two species, whereas water addition decreased nitrate uptake of S. krylovii but promoted the nitrate uptake of A. cristatum. Water interacted with $\mathrm{N}$ to significantly affect plant $\mathrm{N}$ uptake preference, indicating that the effect of water addition on plant $\mathrm{N}$ uptake varies with soil $\mathrm{N}$ availability. At the ambient $\mathrm{N}$ level, water addition enhanced ammonium utilization of $S$. krylovii but decreased that of A. cristatum. At the increased $\mathrm{N}$ level, water addition reduced ammonium uptake and enhanced nitrate uptake in both species. Our results demonstrate that the dominant plant species of the typical Inner Mongolian steppe mainly take up the relatively abundant nitrate rather than the scarce ammonium in this semiarid grassland. Plant preferences for different $\mathrm{N}$ forms changed with resource addition, suggesting that future $\mathrm{N}$ deposition and increases in nitrate availability may promote the growth of the dominant plant species in temperate grasslands, which may contribute to alleviating the global climate change.

ammonium, nitrogen deposition, precipitation change, stable isotope technology, species composition, nitrate doi: 10.1360/TB-2021-1202 